\title{
Calling in "Sick": COVID-19, Opportunism, Pretext, and Subnational Democracy
}

\author{
Matthew Stenberg, Philip Rocco, and Safia Abukar Farole
}

August 3, 2021

As governments sought to manage the Coronavirus pandemic, many pursed a temporary increase in centralized authority, a general tactic of crisis management. However, in some countries, centralization in the name of public health was not the only motive. The COVID-19 response coincided with broader worldwide trends towards democratic backsliding and authoritarian consolidation. Some of these efforts happened while the world was preoccupied with responding to the pandemic without concretely referencing Coronavirus; however, in other cases, public health rationales are clearly and explicitly invoked as a pretext for actions that instead aid the consolidation of regime authority. This has been especially pernicious in subnational democracy, where efforts have been made to undermine the ability of opposition parties to fairly contest in local and regional politics. This paper looks at four cases in which political actors either opportunistically used worldwide distraction from the COVID-19 pandemic or explicitly invoked public health while seeking to undermine long-term domestic contestation in their jurisdictions: Hong Kong, Hungary, Uganda, and the United States. We examine the use of public health as a pretext or opportunity for undermining opposition parties, recentralizing political authority in dominant actors, and inhibiting the fair contestation of elections.

We would like to thank Nisha Bellinger, Kai Yui Samuel Chan, Lucas Dolan, Laura Jakli, Brad Kent, and Todd LaPorte for helpful comments. 


\section{Introduction}

Organizational theory posits that even in the most horizontal organizations, a crisis will centralize decision-making in the hands of a small group of leaders (Hermann 1963;

Holsti 1972; 'T Hart, Rosenthal, and Kouzmin 1993). States are no different, and even liberal, constitutional democracies centralize in response to crises and emergencies (Lazar 2009). States may enact temporary measures to resolve a crisis (Drabek 1986), which would otherwise be seen as unacceptable to their citizens (Annas 2002; Davis and Silver 2004). Crisis can lead to new powers for governments that endure beyond the resolution of the event itself.

The coronavirus pandemic, as a (hopefully) once in a century event, has been no different. Indeed, the COVID-19 pandemic is one where some greater centralization of authority seems necessary. Yet as necessary as many public health measures have been to reduce the spread of the virus, in other cases the pandemic has led leaders to opportunistically consolidate authority. In some cases, Coronavirus has been explicitly invoked as a rationale for this accrual of power, as in the case of the ability to rule by decree given to leaders in Ghana and Hungary (Addadzi-Koom 2020; Guasti 2020). In other cases, like the imposition of the controversial National Security Law in Hong Kong (Propper 2020), COVID-19 was not invoked; however, national governments took advantage of the situation to push through policies to reinforce centralized control that would otherwise be staunchly opposed by other countries, were their leaders not to be distracted by the immediate concerns of stemming the spread of a life-threatening disease. 
Scholars have rightly called attention to the significant impacts that measures taken to reduce the spread of the coronavirus have had on democracy. They have resulted in restrictions on the media, curtailments of the right to assembly, and the postponement of elections. Many of these actions are temporary and have been taken by governments without inclinations towards democratic backsliding (Maerz et al. 2020). However, in other cases where autocratization has progressed, there are likely to be significant longterm impacts to democratic governance (Rapeli and Saikkonen 2020). And while the national-level impacts have garnered significant attention, COVID-19 will also have significant long-term impacts on subnational democracy in countries where we have seen autocratization, even from measures stated to be in the interest of public health. These changes will reduce the possibilities for the opposition to fairly contest elections, to effectively govern, and to exercise oversight.

In this paper we identify two concrete mechanisms through which the Coronavirus pandemic has furthered subnational democratic backsliding: opportunism and pretext. First, building on the literature about crisis response and democratic backsliding, we argue that autocratizing regimes have opportunistically used the global community's distraction during the pandemic to push forth undemocratic reforms, while in other cases public health concerns were used as a pretext to undermine the fair contestation of subnational democracy. While these same mechanisms can also be found nationally, we focus on the subnational level owing to the importance of subnational governments in pandemic response. We then empirically examine our conceptualization in four exploratory cases, where we have seen governmental COVID responses that will have 
long term impacts on subnational democracy: Hong Kong (China), Hungary, Uganda, and the United States. Cases were selected to provide variation across both geography and regime type. Our cases include democratic (United States), hybrid (Hungary), and competitive authoritarian (Uganda) regimes; Hong Kong is also included as a unique case, as a more democratic enclave within an authoritarian single-party state. While these cases also have suffered from democratic backsliding at the national level, we especially focus on subnational democracy, which is equally important for long-term health of democratic societies but often neglected by the literature. Finally, we conclude.

\section{Subnational Democratic Backsliding and COVID-19}

Over the past twenty years we have seen worldwide trends towards autocratization and democratic backsliding (Lührmann and Lindberg 2019). Autocratization is a more encompassing term, accounting for the hardening of authoritarian and hybrid regimes in addition to backsliding democracies. Autocratization often manifests as undermining judicial independence, restricting media freedom, limiting the ability of the opposition to fairly contest elections, and weakening the informal norms governing free societies (Bermeo 2016; Levitsky and Ziblatt 2018). Such processes are often gradual, with the true damage coming from the accumulation of myriad smaller anti-democratic policies (Lührmann and Lindberg 2019; Jakli and Stenberg 2021). For example, in the U.S. case, threats to electoral democracy emerged, following the realignment of the South into the Republican Party, through a series of low-salience contestations of the regime established by the Voting Rights Act of 1965 across several decades, which culminated in the elimination of a core component of voting-rights protections in the Supreme Court's 2013 
decision Shelby County v. Holder (Rhodes 2017). While these are widely discussed in the context of national politics, subnational tiers of government are also subject to autocratization and are crucial for backsliding regimes to maintain their authority.

Subnational politics matter to autocratizing governments for both policy and political reasons. In terms of policy, the past thirty years have resulted in significant political, administrative, and fiscal decentralization, which has been promoted as a major component of successful democratization (Manor 1999; Grindle 2007; Faguet 2014). Substantive policy making occurs in subnational jurisdictions (Trounstine 2009; Hooghe et al. 2016), and subnational jurisdictions are perhaps even more important in pandemics. Geographic spread of the disease is territorially uneven, and local and regional governments are often responsible for implementing policy in many areas (public health, policing, public goods provision) essential for pandemic response (Iverson and Barbier 2020; Rocco, Béland, and Waddan 2020). Some national governments have also sought to shift blame to subnational tiers of government (Smyth et al. 2020). As Greer et al. (2020) note, many national governments pushed responsibilities onto regional and local governments by minimizing or abdicating their own roles. The increasing complexity in intergovernmental relations is an important background factor that shapes how the innate centralizing, anti-democratic tendencies of crisis response ultimately impact local democracy.

Beyond their intrinsic importance as an area of policymaking and implementation, subnational governments are politically valuable to backsliding regimes. They often 
provide a proving ground for the actors seeking to prevent the ruling party from pursuing an anti-democratic agenda. Opposition parties can demonstrate their competence, gaining the credibility needed to compete against dominant parties (Farole 2021; Lucardi 2016). Subnational politicians - for both the ruling party and opposition - often pursue higher office, making it an important for training a pipeline of future political talent to control (Cirone, Cox, and Fiva 2021). Subnational governing units can also be crucial for resource distribution, to reward supporters and maintain long-term political control (Stenberg 2018). Reforms undermining democracy in subnational politics often get less attention, allowing anti-democratic regimes to solidify control at less cost (Jakli and Stenberg 2021). In all of these cases, controlling subnational governments is crucial to ensuring long-term regime stability.

Given that 1) autocratizing and backsliding regimes often seek to centralize authority in the executive and remove the fair contestation of politics, and 2) centralizing authority in the executive is often seen as good practice for responding to crisis, crises are rife with possibilities for abuse by governments wanting to limit the capacity of their opposition. External crises and emergencies, therefore, create structural opportunities to push backsliding forward. The need to respond to rapidly developing situations coherently, quickly, and authoritatively often leads to the centralization of authority - especially in the executive. This can therefore aid in long-term efforts to recentralize authority in national states in ways that limit future fair contestation. Pandemics may be crises that are particularly vulnerable to this type of manipulation. The normal functioning of democratic rule of law can often be suspended as a component of government response. 
Even the most democratic regimes may curtail civil liberties in a state of emergency or in their response to an external crisis. Epidemics and pandemics have in the past led governments to respond to outbreaks by limiting civil liberties to reduce the spread of disease (Barbisch, Koenig, and Shih 2015; Rothstein 2015; Gostin and Hodge Jr. 2020).

All of these restrictions are imposed with the assumption that things may return to "normal" after the crisis ends. But this presupposes a government in favor of the maintenance of democratic norms and principles. When that assumption is broken, if an autocratizing government is interested in accruing more power and control, then crisis becomes an opportunity for further authoritarian consolidation. Democracies become up to $75 \%$ more likely to erode during states of emergency (Lührmann and Rooney 2020), demonstrating that an immediate crisis response can have long-term reverberations for the future fair conduct of politics.

The V-Dem Pandemic Backsliding project systematically analyzes the impacts of COVID-19 response on democracy. On average, they find that the negative impacts on democratic practice are reducing even as the crisis continues (Kolvani et al. 2020). But while some policy choices (including well-intentioned suspensions of elections) may have temporarily impacted the conduct of democracy without threatening its long-term stability, ${ }^{1}$ others are poised to have longer-term, pernicious effects. V-Dem's PanBack index looks at the specific likelihood of changes implemented under COVID-19 having

\footnotetext{
${ }^{1}$ The decision to suspend an election is not intrinsically evidence of backsliding. In French municipal elections, where second round elections were postponed, turnout was historically low, and disease proximity negatively impacted turnout further. However, the decision to postpone was a well-intentioned response to the pandemic and did not clearly advantage any side (Noury et al. 2021).
} 
long-term impacts furthering democratic backsliding. Hungary, Uganda, and the United States all score as having a moderate-to-high risk of COVID-19 responses impacting the country's long-term trajectory. ${ }^{2}$ On a $0-1$ scale, with 0.3 and above being considered high risk, Hungary and the U.S. each scored 0.22, and Uganda scored 0.4 (Edgell et al. 2020). In these cases, there is a real risk that anti-democratic decisions made during the Coronavirus crisis can have substantive, enduring impacts on democracy.

This can happen in one of two ways, and understanding the differences between these two paths can be crucial to understanding how those seeking to safeguard democratic institutions should respond. First, as discussed above, the crisis can be used opportunistically, to take advantage of the distraction of international actors and potentially domestic opponents, who might otherwise mobilize to block reforms. Second, governments can explicitly justify institutional changes and reforms as necessary to respond effectively to the crisis: the crisis itself becomes a pretext. These two pathways are often found together, as our case studies illustrate.

\section{Crisis as Opportunism}

As David Lake notes, opportunism, where actors violate norms and agreements out of self-interest, is widespread in international relations $(1996,13)$. Crises - or other circumstances requiring a great deal of attention from organizations under threat minimize bandwidth to focus on other issues. Studies of firms have shown that when organizational leadership is distracted, adversaries behave opportunistically (Ahmad and Bollaert 2021). In international relations, when the resources of powers are tied up, there

\footnotetext{
${ }^{2}$ Hong Kong is not considered separately from mainland China in this index so is not discussed here.
} 
can be strategic motivation for opportunistic aggression from other states in pursuit of their own foreign policy objectives (Brands and Montgomery 2020).

A transnational crisis therefore changes the strategic calculus of states, creating opportunities for governments to pursue actions that would otherwise attract international outrage, as other states are consumed by managing the situation. ${ }^{3}$ Such "naming and shaming" can be especially common in non-crisis situations as a general diplomatic response, including to antidemocratic reforms (Sedelmeier 2017; Soyaltin-Colella 2020). This use of an adversary's distraction to pursue goals that they might otherwise object to is related to, but distinct from, a national government using diversionary foreign policy to distract its citizens from its own performance (for discussion of diversionary foreign policy, see Smith 1996; Pickering and Kisangani 2005).

However, in responding to a major global crisis like COVID-19, national governments logically have reduced bandwidth to focus on other international behavior that they would normally draw attention to. This distraction, then, becomes an opportunity for states to pursue policies that would otherwise attract more international outrage. This may be a strategic opportunism, where states pursue objectives that might be unpalatable to domestic actors or the international community.

The COVID-19 pandemic has several examples of this type of opportunism, where states pursue objectives they know the international community would strongly object to. In

\footnotetext{
${ }^{3}$ In some cases, these actions may have been otherwise pursued, but they can be opportunistically timed.
} 
these cases, COVID-19 provides cover via the timing of the action, but the policy changes are not justified using public health rationales. This allows states to pursue desired policies that may not be able to be credibly associated with pandemic response. The most prominent example of this is the Chinese government's institution of the Law of the People's Republic of China on Safeguarding National Security in the Hong Kong Special Administrative Region (hereafter National Security Law or NSL), which severely restricted civil liberties in Hong Kong. This move came after one year of protest in Hong Kong (for more, see Ting 2020). The imposition of the NSL led to arrests of opposition politicians and dissidents and had a general chilling effect on the freedom of speech and the press. In Poland, the government amplified its already discriminatory rhetoric against the LGBTQ+ community and moved to severely restrict already limited access to abortion (Golec de Zavala et al. 2020). While in these cases we still do see some international objections (for example, Wintour 2020), they do not come on the scale that we might see were pandemic response not the primary worldwide governing objective.

\section{Crisis as Pretext}

The alternative to using the crisis opportunistically, while would-be critics are distracted, is explicitly justifying increasing autocratization under the pretext of managing the crisis. This does not merely take advantage of critics' distraction but provides a direct rationale to respond to potential criticism: actions become explicitly justified as necessary to effectively respond to the crisis. Scholars argue that governments use pretext to justify a variety of policies and interventions: humanitarian interventions (Goodman 2006), drug trafficking (Mercille 2011), threats from terrorism (Bamford 2005), and fears of domestic 
unrest (Paczkowski 2015). Perhaps the most famous example of such pretext is the Reichstag Fire, ${ }^{4}$ the 1933 burning of the German parliament in Berlin (Mommsen 1985). Adolf Hitler took advantage of the unfettered emergency powers provided by Article 48 of the Weimar Constitution to crackdown on the Communist Party opposition, fundamentally giving Hitler the ability to directly rule as dictator.

Both opportunism and pretext provide avenues for the escalation of autocratization during COVID-19. Pretext is, however, especially pernicious: the abuse of public health rationales to undermine democratic politics has a secondary effect of undermining confidence in legitimate public health measures needed to respond to an ongoing crisis. It is easy to justify actions in the name of public safety and public health that might otherwise be unacceptable (Annas 2002).

This abuse is readily apparent in the COVID-19 pandemic at both the national and subnational levels. In Hungary, the ruling Fidesz party's parliamentary supermajority gave Prime Minister Viktor Orbán the open-ended right to rule by decree to manage the public health threat; Orbán used opportunistically restricted freedom of the press and pushed an anti-LGBTQ+ agenda (Guasti 2020). Opposition efforts to question the imposition of rule by decree were met with accusations that they were impeding the government's ability to stop the spread of coronavirus (Kádár 2020). Ghanaian President Nana Akufo-Addo gained similar prerogatives from the national parliament (AddadziKoom 2020), while India's government invoked the Disaster Management Act to bypass

\footnotetext{
${ }^{4}$ Which, of course, the Nazi Party may have been directly involved in starting (see Hett 2013).
} 
democratic accountability (Thomson and Ip 2020). In these cases, we see national governments clearly pursuing actions designed to limit democratic contestation and civil liberties under the guise of legitimate public health concerns.

We, however, focus especially on the impacts of such measures on subnational democracy, including measures taken both nationally and subnationally. The inherent centralizing tendencies of crisis and emergency response make subnational jurisdictions especially vulnerable, as they are often forced to cede authority, autonomy, and capacity to national governments (see, for example, Meneguzzo et al. 2013). And the role of subnational tiers of government in the backsliding and autocratizing process is too often overlooked as an important location for regime consolidation and anti-democratic practice.

The following four cases (Hong Kong, Hungary, Uganda, and the U.S.) illustrate the ways that responding to the COVID-19 pandemic has been used both opportunistically and as an explicit pretext for undermining subnational democracy. While these cases differ in terms of level of democracy and types of institution, governance in all four countries has been autocratizing over the past several years. We also see the opportunism and pretext strategies mobilized differently across our cases. Figure 1 below depicts our cases on a two-by-two table, with the left axis indicating if actions were motivated primarily by immediate domestic incentives (ie, an on-going electoral campaign), and the top axis indicating the juridical institutional independence of subnational jurisdictions. These cells should not be seen as deterministic, as we may see either strategy pursued in 
either context, or strategies pursued in conjunction. However, we do see that pretext is more readily mobilized where there is weaker subnational institutional independence, and we see Hong Kong move towards this strategy increasingly after the National Security Law weakens Hong Kong's juridical independence.

Figure 1. Strategies for Undermining Democracy in Four Crisis Contexts

\begin{tabular}{|l|l|l|}
\hline & $\begin{array}{l}\text { Weak Subnational } \\
\text { Institutional Independence }\end{array}$ & $\begin{array}{l}\text { Strong Subnational } \\
\text { Institutional Independence }\end{array}$ \\
\hline $\begin{array}{l}\text { Weak Immediate Domestic } \\
\text { Incentives }\end{array}$ & $\begin{array}{l}\text { Hungary } \\
\text { (pretext) }\end{array}$ & $\begin{array}{l}\text { Hong Kong } \\
\text { (opportunism } \rightarrow \text { pretext) }\end{array}$ \\
\hline $\begin{array}{l}\text { Strong Immediate Domestic } \\
\text { Incentives }\end{array}$ & $\begin{array}{l}\text { Uganda } \\
\text { (pretext) }\end{array}$ & $\begin{array}{l}\text { United States } \\
\text { (pretext } \rightarrow \text { opportunism) }\end{array}$ \\
\hline
\end{tabular}

In Hungary and in Uganda, where we have weak subnational institutional independence, we see the national government mobilize pretext as a strategy. In Uganda, the government primarily focuses on policies pertaining to an upcoming election, while in Hungary the government focuses on institutional changes and non-electoral pretext. In cases with greater subnational institutional independence, in both democratic and authoritarian contexts, we see opportunism used in conjunction with pretext. In the United States, we see initial attempts at pretext quickly give way to opportunism as belief in the threat of the virus becomes polarized. And in Hong Kong, we see the Chinese government initially move opportunistically, and then reinforce their recentralization of control and undermining of democracy through specific pretextual justifications relating to pandemic response as institutions are weakened.

\section{Hong Kong}

In recent years, the Chinese national government has made concrete steps to bring Hong Kong more tightly into its orbit. The agreement reached with the United Kingdom for its 
1997 handover to China stipulated that Hong Kong would abide by the "one country, two systems" principle until 2047, maintaining greater freedoms and civil liberties in the Special Administrative Region of Hong Kong than the rest of the country. However, concrete, incremental steps have been taken since 1997 to slowly bring Hong Kong more into line, showing a clear pattern of democratic backsliding and authoritarian encroachment (Fong 2021). As these steps have been taken, there have been increasing movements among Hongkongers to assert their political rights and to advocate for further democracy.

These efforts significantly escalated in 2014 with the Umbrella Movement, a social movement emerging in response to Beijing's moves to restrict the freedom of prodemocracy candidates to run in Hong Kong's Chief Executive elections (Lo 2017). In 2019, protests erupted again, this time over a new proposed extradition law. This larger movement, the Water Revolution, lasted several months, impacting economic activity and ultimately forcing the withdrawal of the proposed law (Ting 2020). However, Beijing also indicated they would be more actively involved in administering Hong Kong in the future (Hui 2020a). In a show of dissatisfaction with the government's response to the protests, pro-democracy parties swept to power in the city's November 2019 elections across the 18 District Councils, with turnout up over 20\% (Lai and Wu 2019).

With the onset of COVID-19, efforts to reassert central government control in Hong Kong again escalated. These efforts have distinct phases that relate to both opportunism and pretext. First, we see the June 2020 implementation of the NSL as a clear move to 
take advantage of the international community being too preoccupied with COVID response to respond as aggressively as they might otherwise. Second, we see the invocation of public health measures as the rationale for suspending the Legislative Council (LegCo) elections in September as an explicit use of pretext.

After the momentum of the Water Revolution, including in the District Council elections, Beijing announced that a new National Security Law would go into effect at the end of June 2020. The NSL sweepingly curtailed freedoms of speech and assembly in Hong Kong, giving the state greater surveillance capabilities and functionally declaring discussions of a democratic Hong Kong to be illegal. While it is entirely possible such a law would be passed absent the pandemic, the PRC was opportunistic with its timing: the announcement and implementation, strategically coordinated while the rest of the world was heavily occupied with responding to the public health crisis, meant that many countries did not respond as strongly as they might have otherwise. Criticism was still widespread (for example, by the UK in Wintour 2020), although stronger measures were largely not pursued. The NSL's passage predictably led many opposition politicians and activists to limit their activities and/or self-censor. Pro-democracy parties disbanded, and many activists were immediately detained (Hui 2020b).

However, subsequent restrictions on political rights in Hong Kong have invoked public health guidelines as explicit pretexts for interfering with the conduct of subnational democracy. In September 2020, Hong Kong Chief Executive Carrie Lam suspended the 2020 LegCo elections for a year. She used emergency powers, explicitly stating that the 
vote could exacerbate the spread of COVID-19 in the city (Cheung, Wong, and Chung 2020). The use of public health rationale to suspend the LegCo elections builds on the NSL's demonstrable chilling effect on Hongkongers publicly engaging in political discourse. LegCo rules already limit the success of initiatives from the pandemocratic opposition (Smyth, Bianco, and Chan 2019), meaning that the calculus to suspend the elections was more about fears of Beijing appearing weak if the opposition was successful than the likelihood of passage of actual legislation that would impact PRC control. Moreover, the decision to suspend the election came after twelve prominent opposition candidates were barred from running (BBC News 2020). This timing suggests that officials decided that suspending the candidates would not sufficiently guarantee proBeijing candidates would win in September, and further measures were needed. It is unlikely that steps to suspend the candidates would be taken if it were already known the election would be delayed for legitimate public health reasons. Since the suspension of the election, many candidates who organized and/or contested the unofficial prodemocracy primaries in July 2020 have been arrested for supposed NSL violations, including LegCo members and academics (Human Rights Watch 2021).

The passage of the NSL itself did not rely on public health justification and was instead merely opportunistically timed to minimize international opposition, so the move to invoke Coronavirus late in the crackdown seems to be a conscious strategic choice to even further limit dissent. But the suspension of LegCo elections was not the only instance of public health being used to limit anti-regime protest. Hong Kong's COVID lockdown was strategically extended to June 5, 2020 (Thiessen 2020), ensuring that the 
traditional demonstrations in Victoria Park on the anniversary of the Tiananmen Square crackdown could not be held at their typical scale (Hernández, Ramzy, and May 2020). Hong Kong police also used public health rationales to justify fining student reporters at public protests (Thomson and Ip 2020, 24). These trends suggest clear uses of COVID-19 as a pretext to minimize public debate about Hong Kong's democratic future.

\section{Hungary}

Since taking power in 2010, the right-wing Fidesz party has consistently pursued policies of democratic backsliding in Hungary, including constitutional reforms, changes to election law, restrictions on media freedom, and limits on judicial independence (BíróNagy 2017; Krekó and Enyedi 2018, among others). Such backsliding has extended to subnational politics, where Fidesz-led city councils altered municipal regulations to reduce oversight and limit fair electoral contestation (Jakli and Stenberg 2021). Hungary’s Prime Minister, Viktor Orbán, has steadily consolidated control over the past 11 years, strategically using populist rhetoric and government funds to ensure success in Hungary's no-longer-fairly contested elections. The onset of the COVID-19 pandemic, however, clearly furthered Fidesz's anti-democratic tendencies at both the national and subnational levels.

In March 2020, Hungary's Parliament, in which Fidesz holds a legislative supermajority, declared a state of emergency in response to COVID-19 (Novak and Kingsley 2020). This open-ended state of emergency gave Orbán the ability to rule by decree; while it could be revoked by the parliament at any time, Fidesz's supermajority ensured that this was a blank check. Orbán used these powers widely: the Hungarian Helsinki Committee 
(2020) NGO tracked 147 uses during the period it was active (March 30 - June 18, 2020).

Among the most notable antidemocratic uses was the imposition of a potential five year jail sentence for "disseminating misleading information" (Guasti 2020, 53). Emergency powers were used for such concerns as increasing the time needed to respond to public information requests to limit public oversight (Kádár 2020), indicating a clear use of coronavirus as a pretext for other anti-democratic measures.

The Hungarian parliament "revoked" the state of emergency in June; however, it was replaced by a state of medical crisis, which continued to allow the government to rule by decree and which could not be revoked by Parliament (Bayer 2020). Orbán strongly emphasized the public health rationale for the state of emergency, stating that it was an enabling factor for Hungary's rapid pandemic response (Bene and Boda 2021, 96-97). While these sequential "states" directly contributed to continued democratic erosion at the national level, they also furthered Fidesz's long-standing goals of consolidating control over subnational politics.

While Fidesz has had considerable success in municipal politics compared to many rightwing dominant party regimes (Stenberg 2018), a pan-opposition coalition managed to defeat Fidesz-backed candidates in some of Hungary's largest cities in 2019 (Hegedüs 2019). This created the opportunity for opposition mayors in cities like Budapest to gain credibility and increase their prominence, ultimately paving the way to challenge the regime. Fidesz, however, has used the COVID-19 pandemic to restrict the independence of municipalities, bringing them further under the control of the center and undermining 
the ability of opposition mayors to both govern effectively and respond to the public health crisis. This differs from many other cases of subnational democratic erosion in the COVID-19 pandemic, where we have often seen public health used as a pretext for the strategic manipulation of elections and campaigns. In Hungary we instead see that the pandemic was used as a pretext for municipal finance reform, which can undermine subnational democracy non-electorally.

Several pieces of legislation implemented early in the stages of pandemic response had concrete impacts on municipal finance: in almost all cases, responding to the pandemic was used as the official rationale. Car tax revenues were shifted to a county-level epidemic protection fund to aid pandemic response (Elöd 2020a); county administration is dominated by Fidesz. The collection of tourism taxes were suspended from April through the end of 2020, ostensibly to help hotels endure fewer overnight guests (Záborszky 2020). While in aggregate these taxes do not make up a significant portion of municipal revenues (car taxes $1.2 \%$, tourism taxes $0.6 \%$ ), there is substantial variance between municipalities, and some budgets are significantly impacted (Bucsky 2020). Parking fees, which are directly paid to municipalities, were also abolished, officially to minimize transmission risk on public transportation (hirado.hu 2020). In 49 cities, largely controlled by the opposition, parking fees are on average $2.6 \%$ of total revenue, rising to 6.5\% for districts in Budapest (Bucsky 2020). Wealthier municipalities were also subjected to a solidarity tax, transferring money to other municipalities even as their own tax revenues were curtailed (Rovó 2020). Orbán's legislation allowed for the creation of special economic zones, removing selected industrial sites from local business tax rolls 
and regulatory oversight (Dezső and Előd 2020). Mayors explicitly alleged that these policies were pretexts used to deprive cities of funding (Csurgó and Sajó 2020); 41 independent and/or opposition mayors issued a joint-statement protesting the cuts and accusing the government of "bleeding local governments" and weakening crisis response (Matalin 2020), as municipalities also incurred increased pandemic-related expenses due at the same time as experiencing a government-imposed revenue shortfall. By depriving opposition-controlled cities of funding, Fidesz undermines their ability to govern effectively, weakening opposition parties in future electoral campaigns.

While many of these decrees expired with the end of the initial state of emergency, the financial shortfalls they caused had long-term effects, and certain consequences, like the special economic zones, were permanent, having enduring fiscal impacts on municipalities. Moreover, subsequent legislation, implemented under the state of medical crisis, has furthered these goals. In December 2020, new economic measures were announced that would halve local business taxes for small and medium sized enterprises for the next two years (Elöd 2020b). For small municipalities, new intergovernmental aid measures from the central government would fill this gap automatically. However, for municipalities with over 25,000 residents, often where the pan-opposition coalition had managed limited success in the 2019 municipal elections, government aid would only be disbursed case-by-case. This is a much larger proportion of local revenue than the taxes reallocated early in the pandemic. Local business taxes make up $26.2 \%$ of total local government revenue (Bucsky 2020). This gives the national government valuable 
leverage over opposition-controlled cities, especially considering the other pandemic measures restricting municipal finance.

\section{Uganda}

Long before the pandemic, Uganda experimented with decentralizing political power from the central government to subnational units (Green 2010). However, the ruling National Resistance Movement (NRM) party, led by President Yoweri Museveni, understood that subnational democracy, and in particular the opening of space for opposition contestation at the local level, could threaten the regime. The NRM's dominance in local elections has slowly eroded over the years. At the highest position in local government (chairperson), the NRM won 82 of 112 seats in the 2016 election (Gibb 2016). In urban local government, however, support for opposition parties is markedly higher. In the January 2021 polls, opposition candidates won the majority of council seats in the country's eleven major cities (Daily Monitor 2021b). Recent developments in Ugandan politics have seen support for opposition parties in local elections expand to other parts of the country. For instance, the popularity of the prominent opposition figure Robert Kyagulani (Bobi Wine) and his new National Unity Party is credited for the NRM's loss of local government seats in traditional strongholds in Central and Eastern Uganda in 2021 (Mufumba 2021). This year's election occurred in the context of an unprecedented global pandemic, with the NRM-led government using pandemic related measures as a pretext to centralize authority and to undermine opposition mobilization at the local level. 
In the early phase of the pandemic, Uganda reported 284 infections and no deaths. However, the government went on to implement one of Africa's strictest lockdowns, closing business, schools, banning public gatherings, severely restricting the use of public transportation, and imposing an eight-and-a-half-hour nightly curfew (Xinhua 2020). In the midst of these harsh and seemingly premature measures, the president stress-tested the ability of political institutions in Uganda to counter his authoritarian overreach, hinting at the possibility of delaying the elections (Biryabarema 2020). While the country's Electoral Commission declined to postpone the elections (Kirabo 2020), the measures introduced by government ostensibly designed to fight the pandemic resulted in political double standards and an unequal playing field for the opposition at the subnational level.

After lockdown restrictions were gradually eased in Uganda in the summer of 2020, the government announced a ban on political rallies (Ssenoga 2020). The stated reason for the ban on rallies was to fight the spread of the coronavirus, and candidates were told to campaign by leaflet, radio, TV, or on the internet (Ssenoga 2020). The enforcement of the ban on campaign rallies especially appeared to target local governments where opposition parties are more popular. For instance, opposition candidate Major General Mugisha Muntu was blocked from campaigning in the Entebbe municipality (Adude 2020). Elsewhere, attempts by opposition candidates to hold rallies for local races were met with a violent police response (Grasse et al. 2020). On the other hand, NRM candidates successfully held rallies throughout the country in different cities, with few wearing face masks, and not practicing social distancing (Uganda Daily 2020). The suspension of in- 
person campaigning was especially devastating to opposition party campaigns. In Uganda, as in many African countries, most interaction between voters and parties for municipal elections occurs at election rallies, as many voters do not have access to television or the internet (Ssenoga 2020). While candidates for higher political office tend to have more visibility through traditional media, candidates for local elections are particularly reliant on face-to-face interactions with constituents.

After adopting a ban on mass rallies, Uganda's Electoral Commission required candidates to campaign through traditional media and online as a substitute for in-person campaigning. Yet, when opposition candidates for municipal elections attempted to access radio stations and TV networks, they were met with arrests and harassment (Draku 2020). In some municipalities, journalists were arrested for interviewing opposition candidates (CPJ 2021). The government also introduced pandemic-related restrictions that targeted non-traditional media. Specifically, two days before the election, the government ordered several social media platforms blocked, including Facebook, WhatsApp, and Twitter (Reuters 2021). This decision had an impact on opposition campaigns in local government elections because the voter base of opposition parties in Uganda is predominantly young, and opposition candidates rely on social media campaigns to mobilize voters in local elections (Anguyo 2021). Traditional media in Uganda is owned by government allies or is state-run, and opposition candidates use social media to directly broadcast their campaign rallies and news conferences to voters (Reuters 2021). In the context of widespread restrictions on physical and digital 
campaigning, turnout was considerably depressed for local elections (Daily Monitor 2021a).

\section{United States}

In the United States, the administration of core democratic rights, including (though not exclusively) the right to vote, occurs at the subnational level. And while the 1965 Voting Rights Act gave the federal government extensive capacity to oversee election administration in jurisdictions with a history of racial disenfranchisement, the U.S. Supreme Court struck down the formula that supported this provision in 2013, allowing Republican state officials to introduce a wave of new franchise restrictions at the subnational level. This move elicited the re-emergence of a round of voter suppression laws, especially in states governed by Republicans. Together with a surge in extreme partisan gerrymanders and a crackdown on labor organizing in swing states, these procedures contributed to an increase in democratic backsliding even prior to the pandemic (Rocco 2021).

The COVID-19 pandemic also presented Republicans with opportunitiessuccessfully leveraged or not—-for contesting electoral democracy in the United States. Not all strategies were equally available to Republicans, however. For example, Republicans had fewer opportunities to use COVID-19 as a pretext for democratic backsliding. This is because Republican elected officials — and ultimately Republican voters - were far less likely than their Democratic counterparts to act swiftly to control the pandemic. At the state level, Republican governors and legislatures generally enacted weaker and shorter nonpharmaceutical interventions than their counterparts in the 
Democratic Party (Adolph et al. 2021). Because of this, it would have been far more difficult for Republicans to simultaneously justify curbs on the grounds of public health while claiming to their constituents that the pandemic did not require serious publichealth interventions. Instead, the evidence suggests Republicans locked themselves into an opportunistic response; throughout the first year of COVID-19, Republicans often leveraged the effects of public health responses to undermine the functioning of core democratic institutions.

Some of the clearest episodes of opportunism in the U.S. surrounded decisions whether and how to delay spring elections, which occurred as the first wave of COVID-19 began to crest, before the development of widespread public-health protocols. Both public health and election officials converged on the idea of delaying primaries as a means of reducing the spread of COVID-19 from in-person voting and avoiding massive reductions in turnout. Between March 13 - the date on which President Trump declared a national emergency under the Stafford Act—and September 1, state officials ultimately delayed 23 of 59 scheduled elections. Even so, lawmakers in several states took actions calibrated to reduce turnout. When decisions by public health and election officials in Ohio triggered a primary delay and a shift to all-mail balloting, Republican leaders in the state's legislature stepped in with a more restrictive set of ballot deadlines, causing thousands of absentee ballot requests to fail to arrive in time and led to a decisive drop in turnout (Rakich 2020).

The pattern in Wisconsin was even more acute, since the April 7 election featured not only a Democratic presidential primary but a Supreme Court race in which Daniel Kelly, 
an incumbent justice appointed by former Republican Governor Scott Walker, was defending his seat against Jill Karofsky, a liberal with Democratic Party bona fides. Governor Tony Evers, a Democrat, took executive action to delay the election and extend the deadline for absentee ballots after Republicans in the state legislature refused to act. Yet on the eve of the election both the Wisconsin Supreme Court and the U.S. Supreme Court — both sharply divided along ideological lines — issued rulings in suits brought by Republicans that reversed Evers' decision (Wisconsin Legislature v. Evers 2020; RNC v. DNC 2020).

The immediate result of the Wisconsin decision was Election Day chaos. The April 7 election a shortage of election officials led to the shuttering all but 5 of 180 polling places in the city of Milwaukee (Spicuzza 2020). Thousands of Wisconsin voters who requested absentee ballots never received them, and decisions about counting absentee ballots varied across jurisdictions (Bice 2020). Polling place consolidation had the effect of suppressing votes, reducing overall turnout in Milwaukee by 8.5 percentage points and turnout among the Black population by about 10.2 percentage points (Morris and Miller 2021). Statewide, however, efforts at voter suppression ran up against a highly mobilized Democratic electorate (Pildes and Stewart III 2020). Across the state, turnout in the April elections was $34 \%$, roughly equivalent to participation in the 2008 primaries and surpassing turnout in 2012. In the end, this meant a decisive win for Judge Karofsky, who defeated the Republican-appointed incumbent with a decisive $55 \%$ of votes.

Chaotic experiences in the primaries - along with the persistent realities of the pandemic - ultimately led officials in 39 states to modify voting procedures to expand 
voting opportunities, including through early voting and no-excuse absentee balloting, extended voter registration deadlines, and extended postmark deadlines for absentee ballots (Ballotpedia 2020). While these changes likely helped to ensure voter turnout did not crater in 2020, the significant increase in turnout during the general election is likely due to increased voter interest in the election rather than these procedural maneuvers (Yoder et al. 2021).

Nevertheless, even before all the votes were counted, President Trump and many Republican officials throughout the country leapt on pandemic-year voting adjustments to support false claims of massive voter fraud. Trump would likely have made these claims regardless of the circumstances, yet as it was his campaign repeatedly anchored its claims about fraud on the widespread use of absentee balloting (Parks and Karson 2020). Despite wide agreement among election officials that the 2020 elections were the "safest in history," claims of voter fraud persisted in the months following the election (Cybersecurity \& Infrastructure Security Agency 2020). Republican efforts to discredit the 2020 election results eventually led to dozens of post-election lawsuits-all dismissed; attempts by members of Congress to halt the election certification; and an armed insurrection at the U.S. Capitol. Several months later, Republicans in nearly 40 states had introduced legislation to tighten voting restrictions, including eliminating noexcuse absentee voting (McCaskill 2021). In this case, it was not the pandemic itself but state election officials' initial reaction to it that provided the impetus for opportunism.

\section{Conclusion}


Responding to the COVID-19 pandemic has required a great deal of attention and an extensive outlay of resources from every government worldwide. The level of political attention on public health has meant that governments have had the opportunity to pursue objectives domestically that other states have not had the bandwidth to address. Some states have pursued democratic backsliding, taking advantage of the innate centralizing tendencies of crisis management to consolidate authority and undermine their opposition. States have done this through two primary mechanisms: opportunism and pretext.

This has not only happened on the national level. We have seen governments use COVID-19 as both an opportunity and a pretext to interfere with subnational politics, including suspending or interfering with the free conduct of elections, depriving opposition controlled municipalities of resources to limit their ability to govern, and cracking down on social movements. These responses, either enabled by the distraction of the international community or through the pretext of direct public health responses, can negatively impact the fair conduct of democratic governance well beyond the resolution of the pandemic.

In Hungary and Uganda, where we see established dominant parties seeking to maintain control, pretext is the dominant subnational strategy, and public health justifications are mobilized as pretexts to limit the effectiveness of potential subnational bases of opposition power. In Hong Kong, pretext is used even more aggressively to prevent opposition success in elections; however, Beijing also opportunistically uses the distraction of the international community to push through a National Security Law to 
more fundamentally limit any future democratic contestation. And in the U.S., virus skepticism from the Republican Party made the use of a pandemic pretext nearly impossible; instead, they opportunistically emphasized supposed threats from pandemic election procedures to try to question the legitimacy of democratic elections altogether, so as to further restrict the franchise going forward.

In all of these cases, there are possibilities for the impacts of the policies implemented during COVID-19 to be durable. They were implemented as part of larger trends towards autocratization designed to assert enduring partisan control at the national and subnational levels. However, the policies focusing on institutional structures may be especially difficult to disentangle. While policies focusing on an election at hand, as in Uganda, enable the current government to maintain control and potentially implement more anti-democratic measures, changes to long-term institutional autonomy and independence have direct impacts that will last beyond the current administration.

Together these cases offer clear illustrations of two potential strategies, opportunism and pretext - which can be used in isolation or in combination - that autocratizing leaders can use in times of crisis to seek to further consolidate control. Understanding the distinctions between these strategies can be critical for ensuring effective responses to threats to democratic institutions.

\section{Works Cited}

Addadzi-Koom, Maame Efua. 2020. "Quasi-State of Emergency: Assessing the Constitutionality of Ghana's Legislative Response to Covid-19." The Theory and Practice of Legislation 8 (3): 311-27. https://doi.org/10.1080/20508840.2020.1777648. 
Adolph, Christopher, Kenya Amano, Bree Bang-Jensen, Nancy Fullman, and John Wilkerson. 2021. "Pandemic Politics: Timing State-Level Social Distancing Responses to COVID-19." Journal of Health Politics, Policy and Law 46 (2): 211-33. https://doi.org/10.1215/03616878-8802162.

Adude, Paul. 2020. "Gen Muntu Blocked from Campaigning in Entebbe.” Daily Monitor, December 1, 2020. https://www.monitor.co.ug/uganda/news/national/gen-muntublocked-from-campaigning-in-entebbe-3215434.

Ahmad, Muhammad Farooq, and Helen Bollaert. 2021. "Investor Distraction and Managerial Attention - International Evidence from Mergers and Acquisitions." SKEMA Business School. https://ssrn.com/abstract=3589309.

Anguyo, Innocent. 2021. "Internet Shutdowns in Uganda Cannot Prevent Political Resistance." Africa at LSE (blog). February 3, 2021. https://blogs.lse.ac.uk/africaatlse/2021/02/03/internet-shutdowns-ugandamuseveni-political-resistance-elections-bobi-wine/.

Annas, George J. 2002. "Bioterrorism, Public Health, and Civil Liberties." The New England Journal of Medicine, 1337-42.

Ballotpedia. 2020. "Changes to Election Dates, Procedures, and Administration in Response to the Coronavirus (COVID-19) Pandemic, 2020.” November 19, 2020. https://ballotpedia.org/Changes_to_election_dates,_procedures,_and_administrati on in response to the coronavirus (COVID-19) pandemic, 2020.

Bamford, James. 2005. A Pretext for War: $\overline{9 / 11}$, Iraq, and the Abuse of America's Intelligence Agencies. Knopf Doubleday Publishing Group.

Barbisch, Donna, Kristi L. Koenig, and Fuh-Yuan Shih. 2015. "Is There a Case for Quarantine? Perspectives from SARS to Ebola." Disaster Medicine and Public Health Preparedness 9 (5): 547-53. https://doi.org/10.1017/dmp.2015.38.

Bayer, Lili. 2020. "Hungary Replaces Rule by Decree with 'State of Medical Crisis."' Politico, June 18, 2020. https:/www.politico.eu/article/hungary-replaces-rule-bydecree-controversial-state-of-medical-crisis/.

BBC News. 2020. "Hong Kong Bars 12 Opposition Candidates from Election," July 30, 2020, sec. China. https://www.bbc.com/news/world-asia-china-53593187.

Bene, Márton, and Zsolt Boda. 2021. "Hungary: Crisis as Usual-Populist Governance and the Pandemic." In Populism and the Politicization of the COVID-19 Crisis in Europe, edited by Giuliano Bobba and Nicolas Hubé, 87-100. Cham: Springer International Publishing. https://doi.org/10.1007/978-3-030-66011-6_7.

Bermeo, Nancy. 2016. "On Democratic Backsliding.” Journal of Democracy 27 (1): 519. https://doi.org/10.1353/jod.2016.0012.

Bice, Daniel. 2020. "Milwaukee Election Commission Votes to Count at Least 390 Absentee Ballots with Postmark Problems." Milwaukee Journal Sentinel, April 13, 2020.

https://www.jsonline.com/story/news/politics/elections/2020/04/13/milwaukeevotes-count-absentee-ballots-postmark-problems/2980259001/.

Bíró-Nagy, András. 2017. "Illiberal Democracy in Hungary: The Social Background and Practical Steps of Building an Illiberal State." In Illiberal Democracies in the EU: The Visegrad Group and the Risk of Disintegration, edited by Pol Morillas, 31-44. Barcelona: CIDOB Editions. 
Biryabarema, Elias. 2020. "Madness' to Hold Uganda Vote If Virus Persists: Museveni." Reuters, May 12, 2020. https://www.reuters.com/article/us-health-coronavirusuganda-politics-idUSKBN22O10R.

Brands, Hal, and Evan Braden Montgomery. 2020. "Opportunistic Aggression in the Twenty-First Century." Survival 62 (4): 157-82. https://doi.org/10.1080/00396338.2020.1792129.

Bucsky Péter. 2020. "Már azelőtt padlóra kerültek az önkormányzatok, hogy a kormány tovább ütötte volna öket | G7 - Gazdasági sztorik érthetően.” April 7, 2020. https://g7.hu/kozelet/20200407/mar-azelott-padlora-kerultek-az-onkormanyzatokhogy-a-kormany-tovabb-utotte-volna-oket/.

Cheung, Tony, Natalie Wong, and Kimmy Chung. 2020. "Hong Kong Leader Delays Elections, Asks Beijing to Resolve Legal Questions.” South China Morning Post, July 31, 2020, sec. News. https:/www.scmp.com/news/hongkong/politics/article/3095461/hong-kong-legislative-council-elections-bepostponed.

Cirone, Alexandra, Gary W. Cox, and Jon H. Fiva. 2021. "Seniority-Based Nominations and Political Careers." American Political Science Review 115 (1): 234-51. https://doi.org/10.1017/S0003055420000416.

CPJ. 2021. "Police Beat, Detain Journalists Covering Opposition Candidates Ahead of Uganda Elections.” Committee to Protect Journalists, January 7, 2021. https://cpj.org/2021/01/police-beat-detain-journalists-covering-oppositioncandidates-ahead-of-uganda-elections/.

Csurgó Dénes, and Sajó Dávid. 2020. "Polgármesterek: Orbán szándékosan vérezteti ki az önkormányzatokat.” Index.hu, April 5, 2020. https://index.hu/belfold/2020/04/05/baranyi_szerint_az_onkormanyzatok_kiverezt etese_a_cel_az_ingyenes_parkolassal/.

Cybersecurity \& Infrastructure Security Agency. 2020. “Joint Statement from Elections Infrastructure Government Coordinating Council \& the Election Infrastructure Sector Coordinating Executive Committees." November 12, 2020. https://www.cisa.gov/news/2020/11/12/joint-statement-elections-infrastructuregovernment-coordinating-council-election.

Daily Monitor. 2021a. "Low Voter Turnout, Irregularities Mar Local Council Elections," January 21, 2021. https://www.monitor.co.ug/uganda/news/national/low-voterturnout-irregularities-mar-local-council-elections-3263940.

—. 2021b. "How Parties Shared Seats in City, Municipal Elections," January 27, 2021. https://www.monitor.co.ug/uganda/news/national/how-parties-shared-seatsin-city-municipal-elections-3270418.

Davis, Darren W., and Brian D. Silver. 2004. "Civil Liberties vs. Security: Public Opinion in the Context of the Terrorist Attacks on America." American Journal of Political Science 48 (1): 28-46. https://doi.org/10.1111/j.0092-5853.2004.00054.x.

Dezső András, and Előd Fruzsina. 2020. "Pénz? Bosszú? Más oka lehet, hogy elvették Gödtől a Samsungot.” Index.hu, April 22, 2020. https://index.hu/belfold/2020/04/22/god_samsung_politika/.

Drabek, Thomas E. 1986. Human System Responses to Disaster: An Inventory of Sociological Findings. New York: Springer. 
Draku, Franklin. 2020. "Has Security Taken over Election Process from EC?” Daily Monitor, November 27, 2020.

https://www.monitor.co.ug/uganda/news/national/has-security-taken-overelection-process-from-ec--3211930?view=htmlamp.

Edgell, Amanda B., Anna Lührmann, Seraphine F. Maerz, Jean Lachapelle, Sandra Grahn, Ana Flavia Good God, Martin Lundstedt, et al. 2020. "Pandemic Backsliding: Democracy During Covid-19 (PanDem), Version 5." www.vdem.net/en/our-work/research-projects/pandemic-backsliding/.

Előd Fruzsina. 2020a. "34 milliárddal sarcolják meg az önkormányzatokat, de minek?" Index.hu, April 7, 2020.

https://index.hu/gazdasag/2020/04/07/gepjarmuadot_elveszi_a_kormany_az_onko rmanyzatoktol_koronavirus_alap_valsag/.

—. 2020b. "Négymilliárd forintos bevételig érvényes az iparüzési adó felének elengedése." Telex, December 23, 2020, sec. Gazdaság. https://telex.hu/gazdasag/2020/12/23/kkv-koronavirus-iparuzesi-ado-elengedeseonkormanyzatok.

Faguet, Jean-Paul. 2014. "Decentralization and Governance." World Development 53 (January): 2-13. https://doi.org/10.1016/j.worlddev.2013.01.002.

Farole, Safia Abukar. 2021. "Eroding Support from Below: Performance in Local Government and Opposition Party Growth in South Africa." Government and Opposition 56 (3): 525-44. https://doi.org/10.1017/gov.2020.7.

Fong, Brian C. H. 2021. "Exporting Autocracy: How China's Extra-Jurisdictional Autocratic Influence Caused Democratic Backsliding in Hong Kong." Democratization 28 (1): 198-218. https://doi.org/10.1080/13510347.2020.1851202.

Gibb, Ryan. 2016. "The Elections in Uganda, February 2016." Africa Spectrum 51 (2): 93-101. https://doi.org/10.1177/000203971605100206.

Golec de Zavala, Agnieszka, Kinga Bierwiaczonek, Tomasz Baran, Oliver Keenan, and Adrian Hase. 2020. "The COVID-19 Pandemic, Authoritarianism, and Rejection of Sexual Dissenters in Poland." Psychology of Sexual Orientation and Gender Diversity, 12.

Goodman, Ryan. 2006. "Humanitarian Intervention and Pretexts for War." American Journal of International Law 100 (1): 107-41. https://doi.org/10.2307/3518833.

Gostin, Lawrence O., and James G. Hodge Jr. 2020. "Balancing Public Health and Civil Liberties." JAMA: The Journal of the American Medical Association 323 (12): 1131-32.

Grasse, Donald, Melissa Pavlik, Hilary Matfes, and Travis Kurtis. 2020. "Opportunistic Repression: Patterns of Civilian Targeting by the State in Response to COVID-19." Working paper.

Green, Elliott. 2010. "Patronage, District Creation, and Reform in Uganda." Studies in Comparative International Development 45 (1): 83-103. https://doi.org/10.1007/s12116-009-9058-8.

Greer, Scott L., Elizabeth J. King, Elize Massard da Fonseca, and Andre Peralta-Santos. 2020. "The Comparative Politics of COVID-19: The Need to Understand Government Responses." Global Public Health 15 (9): 1413-16. 
Grindle, Merilee S. 2007. Going Local: Decentralization, Democratization, and the Promise of Good Governance. Princeton: Princeton University Press.

Guasti, Petra. 2020. "The Impact of the COVID-19 Pandemic in Central and Eastern Europe: The Rise of Autocracy and Democratic Resilience." Democratic Theory 7 (2): 47-60. https://doi.org/10.3167/dt.2020.070207.

Hegedüs, Daniel. 2019. "Hungary’s Sudden Political Reshuffle Broke Orbán's Power Monopoly." German Marshall Fund of the United States. Transatlantic Take (blog). October 18, 2019. https://www.gmfus.org/blog/2019/10/18/hungaryssudden-political-reshuffle-broke-orbans-power-monopoly.

Hermann, Charles F. 1963. "Some Consequences of Crisis Which Limit the Viability of Organizations." Administrative Science Quarterly 8 (1): 61. https://doi.org/10.2307/2390887.

Hernández, Javier C., Austin Ramzy, and Tiffany May. 2020. "Defying Beijing, Thousands in Hong Kong Hold Tiananmen Vigil." The New York Times, June 4, 2020, sec. World. https://www.nytimes.com/2020/06/04/world/asia/tiananmenhong-kong-china.html.

Hett, Benjamin Carter. 2013. Burning the Reichstag: An Investigation into the Third Reich's Enduring Mystery. New York: Oxford University Press.

hirado.hu. 2020. "Az ingyenes parkolás is a járvány lassítását szolgálja,” April 6, 2020. https:/hirado.hu/belfold/kozelet/cikk/2020/04/06/elo-ujabb-tajekoztatot-tart-azoperativ-torzs/.

Holsti, Ole R. 1972. Crisis, Escalation, War. Montreal: McGill-Queen's University Press. Hooghe, Liesbet, Gary Marks, Arjan H. Schakel, Sara Niedzwiecki, Sandra Chapman Osterkatz, and Sarah Shair-Rosenfield. 2016. Measuring Regional Authority: A Postfunctionalist Theory of Governance. Vol. 1. 5 vols. Oxford: Oxford University Press.

Hui, Victoria Tin-bor. 2020a. "Beijing's Hard and Soft Repression in Hong Kong." Orbis 64 (2): 289-311. https://doi.org/10.1016/j.orbis.2020.02.010. . 2020b. "Crackdown: Hong Kong Faces Tiananmen 2.0." Journal of Democracy 31 (4): 122-37. https://doi.org/10.1353/jod.2020.0060.

Human Rights Watch. 2021. "Hong Kong: Mass Arrests of Pro-Democracy Politicians." Human Rights Watch. January 8, 2021. https://www.hrw.org/news/2021/01/08/hong-kong-mass-arrests-pro-democracypoliticians.

Hungarian Helsinki Committee. 2020. "HU COVID-19 Emergency Decrees Tracker." 2020. https://docs.google.com/spreadsheets/d/1t27aU5QYW0pj8PfaNxWuajyPhrwpbO 6TxunRjPnrOhM/.

Iverson, Terrence W., and Edward B. Barbier. 2020. "National and Sub-National Social Distancing Responses to COVID-19.” 8452. Munich: CESifo.

Jakli, Laura, and Matthew Stenberg. 2021. "Everyday Illiberalism: How Hungarian Subnational Politics Propel Single-party Dominance." Governance 34 (2): 315-34. https://doi.org/10.1111/gove.12497.

Kádár, András. 2020. "In Its Nature-How Stealth Authoritarianism Keeps Stealing Along During the Pandemic, and How Can It Be Stopped?" Journal of Human Rights Practice 12 (2): 293-300. https://doi.org/10.1093/jhuman/huaa034. 
Kirabo, Jonah. 2020. "Electoral Commission Says 2021 Elections Will Take Place despite Covid-19 Pandemic." Nile Post, May 20, 2020.

https://nilepost.co.ug/2020/05/20/electoral-commission-says-2021-elections-willtake-place-despite-covid-19-pandemic/.

Kolvani, Palina, Martin Lundstedt, Seraphine F. Maerz, Anna Lührmann, Jean Lachapelle, Sandra Grahn, and Amanda B Edgell. 2020. "Pandemic Backsliding: Democracy and Disinformation Seven Months into the Covid-19 Pandemic." Policy Brief 25. Gothenburg: Varieties of Democracy Institute.

Krekó, Péter, and Zsolt Enyedi. 2018. “Orbán’s Laboratory of Illiberalism.” Journal of Democracy 29 (3): 39-51. https://doi.org/10.1353/jod.2018.0043.

Lai, K. K. Rebecca, and Jin Wu. 2019. "Hong Kong Election Results Mapped." The New York Times, November 24, 2019, sec. World. https://www.nytimes.com/interactive/2019/11/24/world/asia/hong-kong-electionresults.html.

Lake, David A. 1996. "Anarchy, Hierarchy, and the Variety of International Relations." International Organization 50 (1): 1-33. https://doi.org/10.1017/S002081830000165X.

Lazar, Nomi Claire. 2009. States of Emergency in Liberal Democracies. New York: Cambridge University Press.

Levitsky, Steven, and Daniel Ziblatt. 2018. How Democracies Die. New York: Crown.

Lo, Sonny Shiu-Hing. 2017. "Factionalism and Chinese-Style Democracy: The 2017 Hong Kong Chief Executive Election.” Asia Pacific Journal of Public Administration 39 (2): 100-119. https://doi.org/10.1080/23276665.2017.1325620.

Lucardi, Adrián. 2016. "Building Support From Below? Subnational Elections, Diffusion Effects, and the Growth of the Opposition in Mexico, 1984-2000." Comparative Political Studies 49 (14): 1855-95. https://doi.org/10.1177/0010414016666857.

Lührmann, Anna, and Staffan I. Lindberg. 2019. "A Third Wave of Autocratization Is Here: What Is New about It?” Democratization 26 (7): 1095-1113. https://doi.org/10.1080/13510347.2019.1582029.

Lührmann, Anna, and Bryan Rooney. 2020. "Autocratization by Decree: States of Emergency and Democratic Decline." Working Paper. Gothenburg: Varieties of Democracy Institute.

Maerz, Seraphine F., Anna Lührmann, Jean Lachapelle, and Amanda B. Edgell. 2020. "Worth the Sacrifice? Illiberal and Authoritarian Practices during Covid-19." Working Paper 110. Gothenburg: Varieties of Democracy Institute.

Manor, James. 1999. The Political Economy of Democratic Decentralization. Washington, D.C.: World Bank.

Matalin Dóra. 2020. "41 polgármester tiltakozik az önkormányzatok kivéreztetése ellen." Index.hu, April 7, 2020.

https://index.hu/belfold/2020/04/07/polgarmesterek_nyilatkozat_ellenzek_tiltakoz as forraselvonas/.

McCaskill, Nolan D. 2021. “After Trump's Loss and False Fraud Claims, GOP Eyes Voter Restrictions across Nation.” Politico, March 15, 2021. https://www.politico.com/news/2021/03/15/voting-restrictions-states-475732.

Meneguzzo, Marco, Alessandro Sancino, Marcel Guenon, and Gloria Fiorani. 2013. "New Development: The Crisis and European Local Government Reforms." 
Public Money \& Management 33 (6): 459-62.

https://doi.org/10.1080/09540962.2013.836010.

Mercille, Julien. 2011. "Violent Narco-Cartels or US Hegemony? The Political Economy of the 'War on Drugs' in Mexico." Third World Quarterly 32 (9): 1637-53. https://doi.org/10.1080/01436597.2011.619881.

Mommsen, Hans. 1985. "The Reichstag Fire and Its Political Consequences." In Aspects of the Third Reich, edited by H. W. Koch, 62-95. New York: MacMillan.

Morris, Kevin, and Peter Miller. 2021. "Voting in a Pandemic: COVID-19 and Primary Turnout in Milwaukee, Wisconsin." Urban Affairs Review.

Mufumba, Isaac. 2021. "What Are Museveni's Options as Buganda, Busoga Revolt?" Daily Monitor, January 23, 2021.

https://www.monitor.co.ug/uganda/news/national/what-are-museveni-s-optionsas-buganda-busoga-revolt--3266182.

Noury, Abdul, Abel François, Olivier Gergaud, and Alexandre Garel. 2021. "How Does COVID-19 Affect Electoral Participation? Evidence from the French Municipal Elections." Edited by Shang E. Ha. PLoS ONE 16 (2): e0247026. https://doi.org/10.1371/journal.pone.0247026.

Novak, Benjamin, and Patrick Kingsley. 2020. "Hungary's Leader Grabbed Powers to Fight the Virus. Some Fear Other Motives." The New York Times, April 5, 2020, sec. World. https://www.nytimes.com/2020/04/05/world/europe/victor-orbancoronavirus.html.

Paczkowski, Andrzej. 2015. Revolution and Counterrevolution in Poland, 1980-1989: Solidarity, Martial Law, and the End of Communism in Europe. Rochester: University of Rochester Press.

Parks, MaryAlice, and Kendall Karson. 2020. “A Step-by-Step Look at Trump's Falsehoods on Mail-in Voting: Analysis." ABC News, October 1, 2020. https://abcnews.go.com/Politics/step-step-trumps-falsehoods-mail-votinganalysis/story?id=73354979.

Pickering, Jeffrey, and Emizet F. Kisangani. 2005. "Democracy and Diversionary Military Intervention: Reassessing Regime Type and the Diversionary Hypothesis." International Studies Quarterly 49 (1): 23-44. https://doi.org/10.1111/j.0020-8833.2005.00333.x.

Pildes, Richard H., and Charles Stewart III. 2020. "The Wisconsin Primary Had Extraordinarily High Voter Turnout." Washington Post. Monkey Cage (blog). April 15, 2020. https://www.washingtonpost.com/politics/2020/04/15/wisconsinprimary-had-extraordinarily-high-voter-turnout/.

Propper, Eyal. 2020. "The National People's Congress 2020: The Hong Kong National Security Law and China's Enhanced Presence.” INSS Insight 1329. Tel Aviv: Institute for National Security Studies.

Rakich, Nathaniel. 2020. "What Went Down In Ohio's Primary." FiveThirtyEight, May 7, 2020. https://fivethirtyeight.com/features/what-went-down-in-ohios-primary/.

Rapeli, Lauri, and Inga Saikkonen. 2020. "How Will the COVID-19 Pandemic Affect Democracy?:" Democratic Theory 7 (2): 25-32. https://doi.org/10.3167/dt.2020.070204.

Reuters. 2021. "Uganda Bans Social Media Ahead of Presidential Election," January 12, 2021. https://www.reuters.com/article/us-uganda-election-idUSKBN29H0KH. 
Rhodes, Jesse H. 2017. Ballot Blocked: The Political Erosion of the Voting Rights Act. Stanford: Stanford University Press.

RNC v. DNC. 2020.

Rocco, Philip. 2021. "Laboratories of What? American Federalism and the Politics of Democratic Subversion." In Democratic Resilience: Can the United States Withstand Rising Polarization?, edited by Robert Lieberman, Suzanne Mettler, and Kenneth Roberts, 297-319. New York: Cambridge University Press.

Rocco, Philip, Daniel Béland, and Alex Waddan. 2020. "Stuck in Neutral? Federalism, Policy Instruments, and Counter-Cyclical Responses to COVID-19 in the United States." Policy and Society 39 (3): 458-77. https://doi.org/10.1080/14494035.2020.1783793.

Rothstein, Mark A. 2015. "From SARS to Ebola: Legal and Ethical Considerations for Modern Quarantine." Indiana Health Law Review 12 (1): 227-80.

Rovó Attila. 2020. "Orbán Balázs: Elvárható, hogy Budapest is támogassa a szegényebb településeket." Index.hu, June 11, 2020.

https://index.hu/belfold/2020/06/11/orban_balazs_elvarhato_hogy_budapest_is_ta mogassa a szegenyebb telepuleseket/.

Sedelmeier, Ulrich. 2017. "Political Safeguards against Democratic Backsliding in the EU: The Limits of Material Sanctions and the Scope of Social Pressure." Journal of European Public Policy 24 (3): 337-51. https://doi.org/10.1080/13501763.2016.1229358.

Smith, Alastair. 1996. "Diversionary Foreign Policy in Democratic Systems." International Studies Quarterly 40 (1): 133. https://doi.org/10.2307/2600934.

Smyth, Regina, William Bianco, and Kwan Nok Chan. 2019. "Legislative Rules in Electoral Authoritarian Regimes: The Case of Hong Kong's Legislative Council." The Journal of Politics 81 (3): 892-905. https://doi.org/10.1086/703068.

Smyth, Regina, Gulnaz Sharafutdinova, Timothy Model, and Aiden Klein. 2020. "The Russian Power Vertical and the COVID-19 Challenge: The Trajectories of Regional Responses.” PONARS Eurasia Policy Memo 646. PONARS Eurasia.

Soyaltin-Colella, Digdem. 2020. "(Un)Democratic Change and Use of Social Sanctions for Domestic Politics: Council of Europe Monitoring in Turkey." International Political Science Review, June, 0192512120927120. https://doi.org/10.1177/0192512120927120.

Spicuzza, Mary. 2020. “'A Very Sad Situation for Voters': Milwaukeeans Brave Wait Times as Long as 2 1/2 Hours, Top Election Official Says." Milwaukee Journal Sentinel, April 7, 2020. https://www.jsonline.com/story/news/politics/elections/2020/04/07/wisconsinelection-milwaukee-voters-brave-long-wait-lines-polls/2962228001/.

Ssenoga, Geoffrey. 2020. "Why Uganda's Ban on Open-Air Campaigns Could Tilt the 2021 Poll in Museveni's Favour." The Conversation, September 6, 2020. $\mathrm{http}$ ://theconversation.com/why-ugandas-ban-on-open-air-campaigns-could-tiltthe-2021-poll-in-musevenis-favour-144814.

Stenberg, Matthew. 2018. "The Subnational Imposition of a One-Party Regime: Hungarian Local Elections in National Context." Conference Paper presented at the 114th APSA Annual Meeting, Boston, August 30. 
'T Hart, Paul, Uriel Rosenthal, and Alexander Kouzmin. 1993. "Crisis Decision Making: The Centralization Thesis Revisited." Administration \& Society 25 (1): 12-45.

Thiessen, Marc A. 2020. "China Is Using Covid-19 to Throttle Hong Kong's proDemocracy Movement.” Washington Post, May 21, 2020. https://www.washingtonpost.com/opinions/2020/05/21/china-is-using-covid-19throttle-hong-kongs-pro-democracy-movement/.

Thomson, Stephen, and Eric C. Ip. 2020. "COVID-19 Emergency Measures and the Impending Authoritarian Pandemic." Journal of Law and the Biosciences 7 (1): 1saa064. https://doi.org/10.1093/jlb/lsaa064.

Ting, Tin-yuet. 2020. "From 'Be Water' to 'Be Fire': Nascent Smart Mob and Networked Protests in Hong Kong." Social Movement Studies 19 (3): 362-68. https://doi.org/10.1080/14742837.2020.1727736.

Trounstine, Jessica. 2009. "All Politics Is Local: The Reemergence of the Study of City Politics." Perspectives on Politics 7 (3): 611-18. https://doi.org/10.1017/S1537592709990892.

Uganda Daily. 2020. “'Overwhelmed' Police Looks on as NRM Hold Procession in Gulu," November 17, 2020, sec. Politics. https://ugdaily.com/overwhelmedpolice-looks-on-as-nrm-hold-procession-in-gulu/.

Wintour, Patrick. 2020. "China Is Breaking Hong Kong Treaty with UK, Says Boris Johnson." The Guardian, July 1, 2020, sec. World news. http://www.theguardian.com/politics/2020/jul/01/china-is-breaking-hong-kongtreaty-with-uk-says-boris-johnson.

Wisconsin Legislature v. Evers. 2020.

Xinhua. 2020. "Ugandan Security Agencies Start Enforcing Night Curfew to Contain COVID-19 Spread," April 1, 2020. http://www.xinhuanet.com/english/202004/01/c_138935918.htm.

Yoder, Jesse, Cassandra Handan-Nader, Andrew Myers, Tobias Nowacki, Daniel M Thompson, Jennifer A Wu, Chenoa Yorgason, and Andrew B Hall. 2021. "How Did Absentee Voting Affect the 2020 U.S. Election?" Working paper. Stanford.

Záborszky Ede. 2020. "Minden, amit a gazdaságvédelmi akciótervről eddig tudni lehet." Index.hu, April 7, 2020.

https://index.hu/gazdasag/2020/04/07/amit_a_gazdasagvedelmi_akciotervrol_tud ni_lehet/. 